\title{
IZMJENA RJEŠENJA U ŽALBENOM UPRAVNOM POSTUPKU
}

Prof. dr. sc. Marko Šikić*

\author{
UDK 35.077 .2 \\ https://doi.org/10.30925/zpfsr.42.2.3 \\ Ur.: 13. travnja 2021. \\ Pr.: 14. svibnja 2021. \\ Izvorni znanstveni rad
}

\begin{abstract}
Sažetak
Žalba kao redovito pravno sredstvo u upravnom postupku gledano u cjelini uređena je odredbama Zakona o općem upravnom postupku prilično kvalitetno. Međutim, stajalište je autora da je izostalo potpunije i djelotvornije zakonodavčevo uređenje postupka izmjene rješenja u žalbenom stadiju upravnog postupka. Kako bi se dokazala navedena tvrdnja, ponajprije će se analizirati mogućnosti ulaženja $u$ reformatio in melius $i$ reformatio in peius kao najvažnije aspekte navedene etape žalbenoga postupka. U radu se osobita pozornost pridaje pitanju reformatio in peius budući da navedeno pitanje ulazi u same temelje uređenja žalbe kao pravnog sredstva. U zaključku rada ponovno se u kraćim crtama iznose osnovne teze rada te se zalaže za potpunije i učinkovitije normativno uređenje mogućnosti izmjene rješenja u žalbenom upravnom postupku.
\end{abstract}

Ključne riječi: izmjena rješenja; žalba; upravni postupak; reformatio in peius, reformatio in melius.

\section{1. $U V O D$}

Žalba je redovito i najjače pravno sredstvo koje je građanima na raspolaganju u borbi protiv nezakonitih i nepravilnih upravnih akata. ${ }^{1}$ Njome se upravni akt može osporavati zbog svih razloga nezakonitosti koji su utvrđeni u hrvatskoj teoriji upravnog prava, ali i zbog pogrešne primjene slobodne ocjene. Stoga se u žalbenom postupku ispituje i zakonitost i svrhovitost osporenog upravnog akta. ${ }^{2}$ Izvanredna

* Dr. sc. Marko Šikić, redoviti profesor, Pravni fakultet Sveučilišta u Zagrebu; marko.sikic@, pravo.hr. ORCID: https://orcid.org/0000-0002-0146-9391.

1 Pravo na žalbu jamči čl. 18. Ustava Republike Hrvatske, Narodne novine, br. 56/90., 135/97., 113/00., 28/01., 76/10. i 5/14. Zakon o općem upravnom postupku, Narodne novine, br. 47/09. (dalje: ZUP) kao jedno od načela upravnog postupka u čl. 12. predviđa i načelo prava stranke na pravni lijek, kojim se jamči pravo na žalbu i protiv prvostupanjskih rješenja i protiv propuštanje rješavanja u propisanim rokovima (šutnja uprave).

2 V. Dario Đerđa, Opći upravni postupak u Republici Hrvatskoj (Zagreb: Inženjerski biro, 2010.), 246-247. 
pravna sredstva, pak, mogu se u upravnom postupku podnijeti protiv pravomoćnih akata isključivo zbog taksativno navedenih razloga. ${ }^{3}$ Prigovor je $s$ druge strane redovito pravno sredstvo specifične prirode. ZUP ga, naime, uspostavlja, ponajprije kao sredstvo koje se može podnijeti protiv upravnih ugovora i drugih postupanja javnopravnih tijela ili pružatelja javnih usluga, ${ }^{4}$ gdje ima devolutivno ${ }^{5}$ i remonstrativno djelovanje, ${ }^{6}$ ali i kao opće remonstrativno pravno sredstvo. ${ }^{7}$

Iako je upravni spor najvažniji vanjski oblik kontrole rada uprave i iznimno snažan mehanizam zaštite načela zakonitosti u radu tijela javne uprave, tužba $u$ upravnom sporu ograničenijeg je dosega od žalbe u pogledu opsega osporavanja pogrešnih upravnih akata. Upravni spor usmjeren je, nadzoru nad zakonitošću upravnih akata, te je izvan njegovog domašaja pitanje slobodne (diskrecijske) ocjene koja može biti obuhvaćena u tim aktima. ${ }^{8}$

Bitno je naglasiti da je žalba i u rukama javnopravnih tijela najvažnije pravno sredstvo u borbi protiv nezakonitosti u radu javne uprave. Prema tome, žalbenim se postupkom postiže dvostruka svrha - zaštita zakonitosti u djelovanju donositelja upravnog akta i zaštita prava i pravnih interesa subjekata o kojima se odlučuje tim aktom. ${ }^{9}$

ZUP uređujući žalbu kao redovito pravno sredstvo u osnovi nije bitnije odstupao od uređenja kakvo je bilo i u ranijim zakonskim tekstovima. ${ }^{10}$ Autor smatra kako je takvo uređenje, gledajući u cjelini kvalitetno te omogućuje da se i u praksi potencijali žalbe u uvelike i ostvare.

Autor smatra da je u uređenju mogućnosti izmjene rješenja u žalbenom upravnom postupku zakonodavac propustio urediti sva pitanja koja izmjena rješenja nameće te time zakinuo građane, a i pravni sustav u cjelini, za primjenu jednoga suptilnog i vrlo korisnog aspekta žalbe kao pravnog sredstva.

3 V. čl. 123. i čl. 128.-130. ZUP-a.

4 V. st. 3. ranije spomenutog čl. 12. ZUP-a.

5 V. čl. 154. ZUP-a koji uređuje prigovor na upravni ugovor i čl. 157. i 158. ZUP-a koji normiraju prigovor kao pravno sredstvo zaštite od postupanja pružatelja javnih usluga.

6 V. čl. 155. i 156. ZUP-a koji uređuje prigovor kao pravno sredstvo zaštite od postupanja javnopravnih tijela.

7 ZUP prigovoru kao remonstrativnom pravnom sredstvu posvećuje čitavu jednu glavu (drugu) koja ipak broji samo jedan članak. Riječ je o čl. 122. pod naslovom Izjavljivanje prigovora $i$ postupanje po prigovoru.

8 Navedeno ne znači da se tužbom u upravnom sporu ne može osporavati zakonitost akata u kojima je sadržana diskrecijska odluka. Isto tako, predmet upravnog spora može biti i pitanje granica ovlasti diskrecijskog odlučivanja, kao i pitanje svrhe radi koje je diskrecijska ovlast dana. V. čl. 4. st. 2. Zakona o upravnim sporovima, Narodne novine, br. 20/10., 143/12., 152/14., 94/16. i 29/17.

9 V. Ivo Borković, Upravno pravo (Zagreb: Narodne novine, 2002.), 458.

10 Pažljivom usporedbom odredaba novog i starog ZUP-a kojima su uređena pitanja u vezi s postupanjem prvostupanjskog $i$ drugostupanjskog tijela po žalbi nije teško uočiti da su ta pitanja u oba zakona u bitnom uređena na isti način, osim ovlasti drugostupanjskog tijela glede izmjene rješenja. Božo Gagro, „Postupanje po žalbi prema novom Zakonu o općem upravnom postupku“, u: Modernizacija općeg upravnog postupka i javne uprave u Hrvatskoj, ur. Ivan Koprić i Vedran Đulabić (Zagreb: Institut za javnu upravu, Zagreb i Društveno veleučilište u Zagrebu, 2009.), 189. 
U radu će se, stoga analizirati osnovna pitanja koja nameće izmjena rješenja u žalbenom stadiju upravnog postupka. Prema mišljenju autora navedena pitanja proizlaze iz mogućnosti primjene reformatio in melius i reformatio in peius te će se u posebnim poglavljima analizirati upravo navedene mogućnosti. Posebna pozornost posvetit će se pitanju reformatio in peius budući da autori smatraju da navedeno pitanje ulazi u same temelje uređenja žalbe kao pravnoga sredstva.

\section{OSNOVNO O MERITORNOM ODLUČIVANJU DRUGOSTUPANJSKOG TIJELA O ŽALBI I NEKE TERMINOLOŠKE NAPOMENE}

Meritorno odlučujući o žalbi drugostupanjsko tijelo žalbu može odbitit ${ }^{11}$ ili je usvojiti. Ako žalbu usvoji drugostupanjsko tijelo poništava rješenje ${ }^{12} \mathrm{i}$, u pravilu, samo rješava upravnu stvar. ${ }^{13}$ Iznimno, nakon što je poništilo prvostupanjsko rješenje, drugostupanjsko tijelo može dostaviti predmet na ponovno rješavanje prvostupanjskom tijelu. To će učiniti kad je za donošenje novoga rješenja, a s obzirom na prirodu upravne stvari, nužno rješavanje prvostupanjskog tijela. ${ }^{14}$ Također, drugostupanjsko tijelo će i kod donošenja prvostupanjskog rješenja nenadležnog tijela takvo rješenje poništiti te dostaviti predmet nadležnom tijelu na rješavanje. ${ }^{15}$

Pitanje koje se ovdje postavlja jest mogu li drugostupanjska ili prvostupanjska tijela, nakon poništavanja pobijanog rješenja, donijeti novo rješenje koje je za žalitelja povoljnije (reformatio in melius) odnosno nepovoljnije (reformatio in peius) od pobijanoga rješenja? ${ }^{16}$

ZUP (djelomično i nejasno) odgovara samo na pitanje mogućnosti donošenja nepovoljnijega rješenja. Naime, čl. 118., pod naslovom Izmjena rješenja propisuje načelnu zabranu reformatio in peius te iznimke od te načelne zabrane:

(1) Drugostupanjsko tijelo ne može izmijeniti prvostupanjsko rješenje na štetu stranke koja je izjavila žalbu.

(2) Iznimno, drugostupanjsko tijelo može izmijeniti prvostupanjsko rješenje na

11 V. čl. 116. ZUP-a pod naslovom Odbijanje žalbe.

12 Čl. 117. ZUP-a pod naslovom Poništavanje rješenja.

13 V. čl. 117. st. 1. ZUP-a.

14 V. čl. 117. st. 2. ZUP-a.

15 V. čl. 117. st. 3. ZUP-a.

16 U hrvatskoj teoriji upravnog prava pitanje reformatio in melius i reformatio in peius promatra se uglavnom iz točke žalbenoga zahtjeva (petita). Ističe se, naime, kako u svemu postoje tri mogućnosti za meritorno odlučivanje nadležnih tijela: prema petitu (usvajanje žalbe), protiv petita (odbijanje žalbe) ili mimo petita (reformatio in peius i reformatio in melius). V. tako: Ivo Krbek, Zakon o opštem upravnom postupku (Zagreb: Tisak jugoslovenske štampe d. d., 1931.), 158; Velimir Ivančević, Institucije upravnog prava (Zagreb: Pravni fakultet u Zagrebu, 1983.), 426 i Borković, Upravno pravo, 464-465. Mišljenje je autora da je takvo gledište preusko. Do reformatio in peius i reformatio in melius dolazi svakako nakon što je nadležno tijelo usvojilo žalbu. Nadalje, vrlo je moguće da stranka u žalbi nije niti iznijela žalbeni zahtjev ili ga je vrlo teško prepoznati (ZUP čl. 108. koji uređuje sadržaj žalbe niti ne traži da se takav zahtjev navede $\mathrm{u}$ žalbi). Prema tome, pitanje reformatio in peius i reformatio in melius potrebno je promatrati iz točke pobijanoga rješenja. 
štetu stranke koja je izjavila žalbu samo iz razloga zbog kojih bi to rješenje moglo oglasiti ništavim ili poništiti, ako nije drukčije propisano.

Stoga će se u radu najprije analizirati mogućnosti i dosezi reformatio in melius u žalbenom stadiju upravnog postupka te kritizirati zakonodavčevo sustezanje od propisivanja navedenog smjera izmjene rješenja.

$\mathrm{S}$ obzirom na to da je pitanje mogućnosti ulaženja u reformatio in peius jedno od temeljnih pitanja uređenja žalbe kao pravnoga sredstva, te da ga je zakonodavac propustio preciznije i potpunije urediti, navedena će se problematika opširnije i pozornije razmotriti.

Ponajprije će se razjasniti moguće terminološke nejasnoće u ZUP-u, a koje se tiču slučajeva kada u postupku u povodu žalbe nadležna tijela mogu stavljati izvan snage postojeća prvostupanjska rješenja te donositi nova.

Takoje, najprije nužno istaknuti kako u postupanju u povodu žalbe prvostupanjsko tijelo (kojemu se žalba i predaje), može, ako utvrdi da je žalba osnovana u cijelosti ili djelomično, zamijeniti pobijano rješenje novim (ako se ne dira u prava trećih osoba). ${ }^{17}$ Dakle, izraz koji u opisanoj situaciji zakonodavac upotrebljava jest zamjena rješenja, pa je prema tome, zamjena rješenja moguća samo u prvostupanjskom žalbenom postupku. ${ }^{18}$

U drugostupanjskom žalbenom postupku, drugostupanjsko tijelo može intervenirati u prvostupanjsko rješenje tako da ga poništi zbog nekog (ili nekih) od razloga navedenih u čl. 117. st. 1. i 3. ZUP-a, te nakon toga postupi na način kako je ranije i opisano (samo riješi ili dostavi predmet prvostupanjskom tijelu na ponovno rješavanje).

Stajalište je autora da izraz izmjena rješenja iz čl. 118. ZUP-a označava i situaciju kada drugostupanjsko tijelo nakon poništavanja pobijanog rješenja donosi novo, ali i kada takvo rješenje, po dostavljenom predmetu, donosi prvostupanjsko tijelo.

U nastavku će rada takva razmišljanja biti dodatno pojašnjena. Pojasnit će se i stajalište autora da je izraz izmjena rješenja zakonodavac trebao proširiti i na slučajeve interveniranja u zakonita i pravilna rješenja.

\section{REFORMATIO IN MELIUS}

Rreformatio in melius, podrazumijeva da nadležna tijela, nakon usvajanja žalbe i poništavanja pobijanog rješenja, mogu donijeti novo rješenje koje je za podnositelja žalbe povoljnije od pobijanog rješenja. Iako je možda reformatio in melius sama po sebi razumljiva i proizlazi iz smisla žalbe kao pravnog lijeka, zakonodavac je takav način izmjene rješenja trebao normirati - u prvom redu zbog toga da se utvrde moguće granice reformacije.

Mišljenje je autora da su granice reformatio in melius u postupcima po

17 V. čl. 113. st. 5. ZUP-a. Zamjenom rješenja pobijano rješenje stavlja se izvan snage. Iako to nije izrijekom navedeno u ZUP-u autor smatra da bi ispravniji pristup (ponajprije iz aspekta pravne sigurnosti) bio da prvostupanjska tijela poništavaju pobijana rješenja te nakon toga donose nova.

18 V. o navedenom i u: Alen Rajko, Zamjena i izmjena rješenja u prvostupanjskom upravnom postupku, Ius Info, 15. ožujak 2016, https://www.iusinfo.hr/aktualno/u-sredistu/25513. 
službenoj dužnosti isključivo u pravnoj normi, a da u slučajevima vođenja postupaka na zahtjev stranaka okviri reformatio in melius se moraju pronaći u zahtjevu stranke postavljenog tijekom prvostupanjskog postupka. Naime, ako bi nadležno tijelo i okvire za reformatio in melius tražilo u pravnoj normi upuštalo bi se u disponiranje zahtjevom stranke što nadležno tijelo ni smije ni treba činiti. ${ }^{19}$

Poseban i važan oblik reformatio in melius je i mogućnost izmjene zakonitih i pravilnih prvostupanjskih rješenja. Naime, nadležna tijela u ponovnim postupcima nakon poništavanja rješenja mogu utvrditi da se svrha takvih, zakonitih i pravilnih rješenja mogla postići sredstvima koja su za stranku povoljnija te se postavlja pitanje mogu li izmijeniti i takva rješenja u korist stranke.

Stajalište je autora da se zakonodavac za takvu mogućnost u uređenju reformatio in melius trebao odlučiti zbog izričitog uvođenja načela razmjernosti u hrvatski opći upravni postupak..$^{20}$ Primjena navedenoga načela podrazumijeva i suptilan pristup javnopravnih tijela pri nametanju obveza stranci, ali i njihovu brigu da stranke što lakše ostvare i zaštite svoja prava. Ako je već prvostupanjsko tijelo pri rješavanju propustilo slijediti navedene aspekte načela razmjernosti, mišljenje je autora da ne bi trebale biti zapreke da se u žalbenom upravnom postupku ispravi takav propust. Zakonodavac je trebao izrijekom omogućiti izmjenu zakonitih i pravilnih rješenja u korist stranke u postupku u povodu žalbe, te time razraditi načelo razmjernosti i obogatiti upravni postupak. ${ }^{21}$

19 Zakonom o preuzimanju Zakona o općem upravnom postupku, Narodne novine, br. 53/91. i 103/96. (dalje: ZUP-1991) u Republiku Hrvatsku izrijekom je preuzet bivši savezni jugoslavenski Zakon o općem upravnom postupku u pročišćenom tekstu objavljenom u Službenom listu SFRJ, br. 47/86., ali s nizom izmjena i dopuna. ZUP 1991. normirao je reformatio in melius u postupcima pokrenutima na zahtjev stranke. Čl. 244. st. 1. ZUP-a 1991. propisivao je, naime, sljedeće: $U$ cilju pravilnog rješenja stvari drugostupanjski organ može u povodu žalbe izmijeniti prvostepeno rješenje u korist žalioca $i$ mimo zahtjeva postavljenoga $u$ žalbi, a u okviru zahtjeva postavljenoga u prvostupanjskom postupku, ako se time ne vrijeđa pravo druge osobe.

U upravnopravnoj teoriji isticalo se da je na ovaj način ZUP-1991. utvrdio ograničenje djelovanja praeter petitum (mimo zahtjeva) računajući i s mogućnošću da je prije završetka postupka stranka izmijenila svoj zahtjev (proširila, odnosno postavila drukčiji). ZUP 1991. također je stavio prepreku tom rješavanju u stvarima s kontrarnim strankama - reformacija je uvjetovana time da se ne vrijeđa pravo druge osobe. V. Ivančević, Institucije upravnog prava, 426.

Također, s obzirom na to da ZUP 1991. nije propisivao granice reformatio in melius u postupcima pokrenutima po službenoj dužnosti bilo je zauzeto stajalište, prema kojem bi u tim postupcima stranka trebala posebnim podneskom tijekom vođenja prvostupanjskog postupka postaviti određeni zahtjev. V. Slavoljub Popović, Komentar Zakona o opštem upravnom postupku (Beograd: Savremena administracija, 1987.), 570. Kako je i istaknuto u radu u postupcima po službenoj dužnosti stranke ne bi trebale postavljati nikakve posebne zahtjeve, već bi okvire reformacije in melius nadležno tijelo trebalo tražiti samo u pravnoj normi.

20 V. čl. 6. ZUP-a pod naslovom Načelo razmjernosti u zaštiti prava stranaka i javnog interesa.

21 ZUP-1991, koji izrijekom nije predviđao načelo razmjernosti, propisivao je čl. 243. st. 2. mogućnost izmjene zakonitih rješenja: Ako drugostupanjski organ utvrdi da je rješenje pravilno u pogledu utvrđenih činjenica i u pogledu primjene zakona, ali da se svrha zbog koje je rješenje doneseno može postići i drugim sredstvima povoljnijima za stranku, izmijenit će se prvostupanjsko rješenje u tom smislu. 


\section{REFORMATIO IN PEIUS}

Zabrana reformatio in peius u svom izvornom, kaznenoprocesnom, značenju zabrana je da pravni lijek za okrivljenika uzrokuju nepovoljniju sudsku odluku od pobijane, ako je samo okrivljenik podnio taj pravni lijek. Navedena zabrana ne veže samo viši sud koji o pravnom lijeku odlučuje, nego i niži, kojemu je viši sud, ukinuvši presudu u povodu pravnog lijeka podnesenog samo u okrivljenikovu korist, vratio predmet na novo odlučivanje. Stoga se može reći da zabrana reformacije in peius vrijedi za sveukupno trajanje kaznenog postupka kojemu je u ishodištu pravni lijek podnesen samo u korist okrivljenika, tzv. apsolutni karakter zabrane. Iako bi se, prema tome, kod suda koji odlučuje o takvom pravnom lijeku ili kod nižeg suda pojavila vjerojatnost postojanja i nekih drugih činjenica, koje bi dovele do promjene pobijane presude, taj ih sud ne smije utvrditi ako bi to dovelo do izmjene presude na štetu okrivljenika. Pritom nije važno je li riječ o činjenicama koje bi dovele samo do izricanja strože kazne ili kakve druge kaznene mjere ili o činjenicama koje bi dovele i do osude za teže kazneno djelo. Utvrđenje bilo koje od tih činjenica znači povredu zabrane reformatio in peius. Navedena je povreda predviđena kao, tzv. apsolutno bitna povreda odredaba kaznenog postupka. Strogim pridržavanjem zabrane reformatio in peius zakonodavac želi zajamčiti ostvarivanje ustavnog prava okrivljenika na žalbu protiv pojedinačnih akata državne vlasti. Kad takve zabrane ne bi bilo okrivljenik bi se često, zbog bojazni da će žalbom prouzročiti utvrđivanje činjenica na svoju štetu, mogao ustezati koristiti to svoje ustavno pravo.22

Kad se reformatio in peius promatra u sklopu građanskoga parničnog procesnog prava tada se ističe i kako instancijski sud nije ovlašten preinačiti pobijanu presudu na štetu stranke koja je uložila pravni lijek. Pravilo o isključenju mogućnosti preinačenja presude na štetu stranke koja je uložila pravni lijek u građanskom procesnom pravu temelji se na načelu dispozicije i na pravilima o pravomoćnosti. ${ }^{23}$ Posebno se navodi i da s obzirom na navedena načela isključenje mogućnosti reformatio in peius proizlazi $i$ bez potrebe posebnog propisivanja takve zabrane. Naime, protivnik koji nije uložio žalbu protiv presude u dijelu u kome je ona za njega nepovoljna, stvorio je uvjete za to da taj dio presude postane pravomoćan. Treba presumirati da je, ne ulažući žalbu, dispozitivno pristao na njezin sadržaj. Kad bi žalbeni sud unatoč tome mijenjao sadržaj ovoga dijela presude na štetu bilo koje od stranaka, on bi time izvršio apsolutno bitnu povredu procesnog prava prekoračenjem tužbenog zahtjeva, a ogriješio bi se i o načelo pravomoćnosti (ne bis in idem). ${ }^{24}$

Vezano za upravni postupak u teoriji upravnog prava o pitanju zabrane reformacije na štetu žalitelja počelo se raspravljati već i prije nego što je uopće

22 V. Davor Krapac, Kazneno procesno pravo, prva knjiga: institucije (Zagreb: Narodne novine, 2015.), 116. i 117.

23 V. Siniša Triva, Rječnik građanskog procesnog prava (Zagreb: Informator, 1968.), 325. U građanskoprocesnom smislu bitno je naglasiti i kako zabrana reformatio in peius vrijedi samo ako je samo jedna stranka u parnici uložila pravni lijek. Ako su to učinile obje stranke, svaka protiv dijela u kojem nije uspjela ova zabrana, prema prirodi stvari, ne vrijedi.

24 V. Siniša Triva, Mihajlo Dika, Građansko parnično procesno pravo (Zagreb: Narodne novine, 2004.), 712-713. 
i došlo do prvog kodificiranja općeg upravnog postupka (dakle prije 1925. kada je Austrija prva u svijetu to učinila). Navodilo se kako su argumenti za zabranu reformacije jaki: gubi se povjerenje u pravnu sigurnost, a dopustivost reformacije na štetu žalitelja djeluje prohibitivno te tako pravnozaštitni smisao žalbe dolazi na granicu farse. ${ }^{25}$

Međutim, već se i u ranijim teoretskim radovima upozoravalo i na neke posebnosti na koje treba računati kod žalbe u upravnom postupku. Isticalo se, tako, na prvom mjestu kako drugostupanjsko tijelo u upravnom postupku vrlo rijetko nastupa kao sud koji ima konačno riješiti spor među kontrarnim strankama parničnog postupka, već u pravilu djeluje u jednostranačkim stvarima s dvije funkcije: da kao instancija ispituje zakonitost akata, ali i da kao viša upravna vlast djeluje kao nadzorna nad radom niže. Za potonju funkciju trebalo bi biti važno da taj nadzor ima zadaću provjeriti je li prvostupanjsko tijelo pri donošenju svoje odluke uzelo u obzir javni interes. To, pak, ima posljedicu da se mora ocijeniti čitavi pobijani akt bez obzira na vrstu pogreške, ali s obzirom na njezinu težinu, kao i bez obzira na opseg zahtjeva iznesenog u žalbi. ${ }^{26}$

No, takve početne ideje nisu mogle zadovoljiti zahtjeve koji proizlaze iz načela pravne države u kojoj uprava postaje sve jače vezana zakonitošću. Tako se navodi kako je izvorna teza o širokoj dopustivosti reformatio in peius samo neznatan pomak iz stanja u kojem uprava može činiti što god hoće, dok je zakon ne ograničava. Prema tome, pitanje reformatio in peius trebalo je i preobraziti od pravila dopustivosti u pravilo nedopustivosti, uz odmak da postoje i razlozi društvene, ali i čisto pravne prirode koji apsolutnu zabranu reformatio in peius čine pravno neprihvatljivom za upravni postupak. ${ }^{27}$

Upravo je takav pristup zauzet u ZUP-u 1991. koji je čl. 244. st. 2. propisivao, da u cilju pravilnog rješenja stvari drugostupanjski organ može u povodu žalbe izmijeniti prvostupanjsko rješenje na štetu žalioca, ali samo iz kojega od razloga predviđenih u čl. 263., 266. i 267. ovog zakona.

ZUP 1991., prema tome, propisivao je i pravilo zabrane reformatio in peius uz izričito navođenje slučajeva kada je takva reformacija dopuštena. Riječ je o slučajevima koji su mogli dovesti do primjene sljedećih izvanrednih pravnih sredstava uređenih odredbama ZUP-a 1991.: poništavanja i ukidanja po pravu nadzora, ${ }^{28}$ izvanrednog ukidanja ${ }^{29}$ i proglašavanja rješenja ništavim. ${ }^{30}$

Teorija je dopuštanje reformacije u žalbenom postupku opravdavala ponajprije kao neku vrstu preventivne mjere kojom se uklanja potreba da se kasnije dira u prava koja je stranka počela vršiti nakon što je upravni akt postao konačan. ${ }^{31}$

25 V. o navedenom u: Ivančević, Institucije upravnog prava, 423.

26 Ivančević, Institucije upravnog prava, 423-424.

27 Ivančević, Institucije upravnog prava, 424.

28 Razloge za poništavanje i ukidanje po pravu nadzora uređivao je čl. 263. ZUP-a 1991.

29 Razloge za izvanredno ukidanje propisivao je čl. 266. ZUP-a 1991.

30 Razloge za proglašavanje rješenja ništavim navodio je čl. 267. ZUP-a 1991.

31 V. Ivančević, Institucije upravnog prava, 425: Sva tri slučaja koji su navedeni kao pravni razlozi neprihvatljivosti apsolutne zabrane reformacije na štetu žalitelja izrijekom su utvrđeni $u$ čl. 244 st. 2 ZUP-a, koji se izravno poziva na šire taksativno propisane razloge poništavanja $i$ 
ZUP je također, kako je i navedeno na početku rada, u čl. 118. st. 1. proklamirao načelnu zabranu reformatio in peius. Međutim, govoreći o iznimkama od navedenoga pravila čl. 118. st. 2. propisao je da drugostupanjsko tijelo može izmijeniti prvostupanjsko rješenje na štetu stranke koja je izjavila žalbu samo iz razloga zbog kojih bi to rješenje moglo oglasiti ništavim ili poništiti, ako nije drukčije propisano. ${ }^{32}$

Dakle, uz izričito navođenje razloga navedenih kod normiranja izvanrednog pravnog sredstva oglašivanja rješenja ništavim, ${ }^{33}$ ZUP je uređujući ostale iznimke od zabrane reformacije in peius naveo samo opći pojam „poništavanje“.

Mišljenje je autora da je izričito pozivanje na razloge ništavosti kao iznimke od načelne zabrane reformacije in peius u potpunosti opravdano i logično. Ništavost najteži oblik nezakonitosti, ništavi akti opterećeni su pogreškom najjačeg intenziteta te pravno niti ne postoje i ne stječu svojstvo pravomoćnosti. ${ }^{34}$ Prema tome, nema nikakvog razloga za opravdavanje zabrane reformatio in peius kada su akti opterećeni nekim od razloga koji ih čine ništavim. Drugostupanjsko tijelo tu samo sprječava daljnju ,,agoniju“ stranke, koja živi u „iluziji“ da joj određena prava pripadaju i da su joj ikada pripadala.

Nažalost, navođenjem samo općenitog pojma „poništavanje“ zakonodavac je nepotrebno otvorio prostor za tumačenja koja razloge za ulaženje u reformaciju in

ukidanja konačnog rješenja po pravu nadzora (čl. 262), izvanrednog ukidanja izvršnog rješenja (čl. 265) i oglašavanja rješenja ništavim (čl. 266). To pripada među one „osobite slučajeve poništavanja, ukidanja i mijenjanja rješenja" (naslov glave XVI) koji su u pravilu nepoznati u sudskim postupcima, ali su neophodni u djelovanju uprave jer se bez njih ne mogu ukloniti grube nezakonitosti do kojih je došlo u njezinu radu. Ako se s izvjesnom rezigniranošću stranka mora pomiriti s takvim zahvatima pošto je već akt postao konačan u upravnom postupku i ona započinje ostvarivati stečeno ovlaštenje (dodajmo: nezakonito), to još nije argument kojim bi se osnovano moglo kritizirati relativno široko odstupanje od zabrane reformacije u postupku po žalbi. Naprotiv, prije bi se moglo reći da je dopuštanje reformacije u žalbenom postupku opravdanije kao neka vrsta preventivne mjere kojom se uklanja potreba da se kasnije dira $u$ prava koja je stranka počela vršiti pošto je upravni akt postao konačan.

Kakvom pravnom logikom se može zabranom rješavanja in peius pogodovati stranci da se koristi ovlaštenje s kojim nije posve zadovoljna jer samo djelomično odgovara zahtjevu stavljenom u prvostupanjskom postupku, a radi se o stvari iz sudske nadležnosti?

32 I ZUP u uređivanju reformatio in peius ponajprije ima pred očima jednostranačke upravne stvari, koje su u upravnom postupku prevladavajuće. U dvostranačkim ili višestranačkim upravnim stvarima, u kojima su stranke u kontrarnom položaju, zabrana reformatio in peius ne odnosi se na stranku koja nije izjavila žalbu.

33 Čl. 128. ZUP-a pod naslovom Oglašivanje rješenja ništavim u st. 1. navodi razloge koji mogu dovesti do oglašivanja rješenja ništavim:

(1) Rješenje će se oglasiti ništavim:

1. ako je doneseno u stvari iz sudske nadležnosti,

2. ako je doneseno u stvari o kojoj se ne može rješavati u upravnom postupku,

3. ako njegovo izvršenje nije pravno ili stvarno moguće,

4. ako se njegovim izvršenjem čini kazneno djelo,

5. ako je doneseno bez prethodnog zahtjeva stranke, a na koje stranka naknadno izričito ili prešutno nije pristala,

6. ako sadržava nepravilnost koja je po izričitoj zakonskoj odredbi razlog za ništavost rješenja.

34 V. Đerđa, Opći upravni postupak u Republici Hrvatskoj, 296. 
peius pronalaze i tamo gdje ih se, prema shvaćanju autora, ne bi niti trebalo tražiti.

Naime, s obzirom na to da ZUP propisuje razloge koji dovode, ili mogu dovesti, do poništavanja rješenja čl. 117., kojim uređuje mogućnost poništavanja rješenja u žalbenom upravnom postupku kao posljedicu usvajanja žalbe te čl. $123 .{ }^{35}$ i $129 .{ }^{36}$ kojima normira izvanredna pravna sredstva obnove postupka i poništavanja i ukidanja nezakonitog rješenja, postavlja se pitanje je li namjera zakonodavca bila omogućiti reformaciju in peius zbog svih razloga koji su navedeni u spomenutim člancima? $?^{37}$

Mišljenje je autora da se pri odgovoru na navedeno pitanje treba krenuti od činjenice da čl. 118. st. 1. ZUP-a utvrđuje načelnu zabranu reformatio in peius te da je svaka mogućnost ulaženja u takvu reformaciju stroga iznimka od navedenoga pravila. Dopuštanje reformacije in peius u određenim situacijama proizlazi primarno iz dužnosti nadležnih tijela da u žalbenom postupku paze i na zaštitu javnog interesa.$^{38}$ Prema tome, izvjesno je da se pri tumačenju čl. 118. st. 2. ZUP-a

35 Čl. 123. ZUP-a propisuju se razlozi koji mogu dovesti do obnove postupka. To su:

1. ako se sazna za nove činjenice ili stekne mogućnost da se upotrijebe novi dokazi koji bi, sami ili u vezi s već izvedenim i upotrijebljenim dokazima, mogli dovesti do drukčijeg rješenja da su te činjenice, odnosno dokazi bili izneseni, odnosno upotrijebljeni u prijašnjem postupku,

2. ako je rješenje povoljno za stranku doneseno na temelju neistinitih navoda stranke kojima je službena osoba dovedena u zabludu,

3. ako je rješenje donijela osoba koja nije bila ovlaštena za njegovo donošenje ili osoba koja je morala biti izuzeta,

4. ako kolegijalno tijelo koje je donijelo rješenje nije rješavalo u propisanom sastavu ili ako za rješenje nije glasovala propisana većina,

5. ako osobi koja je trebala sudjelovati u svojstvu stranke nije bila dana mogućnost sudjelovanja u postupku,

6. ako stranku nije zastupao zakonski zastupnik,

7. ako osobi koja je sudjelovala u postupku nije bila dana mogućnost da se služi svojim jezikom ili pismom,

8. ako je rješenje doneseno na temelju lažne isprave ili lažnog iskaza svjedoka ili vještaka ili je posljedica kakvog kaznenog djela,

9. ako se rješenje temelji na presudi donesenoj u sudskom postupku, a ta je presuda pravomoćno ukinuta,

10. ako se rješenje temelji na prethodnom pitanju, a nadležni sud ili javnopravno tijelo o tom je pitanju kasnije odlučilo u bitnim točkama drukčije.

36 Čl. 129. ZUP-a pod naslovom Poništavanje i ukidanje nezakonitog rješenja u st. 2. i 3. propisuje razloge za poništavanje i ukidanje rješenja:

(2) Rješenje kojim je stranka stekla neko pravo može se poništiti:

1. ako ga je donijelo nenadležno javnopravno tijelo ili je rješenje doneseno bez zakonom propisane suglasnosti, odobrenja ili mišljenja drugoga javnopravnog tijela,

2. ako je u istoj stvari već doneseno pravomoćno rješenje kojim je ta upravna stvar drukčije riješena.

(3) U slučaju očite povrede materijalnog propisa, rješenje kojim je stranka stekla neko pravo može se poništiti ili ukinuti ovisno o prirodi upravne stvari i posljedicama koje bi nastale poništenjem ili ukidanjem rješenja.

37 Iako je poništavanje rješenja moguće i prema čl. 20., 82. i 146. ZUP-a autor smatra da navedene članke, prema prirodi stvari, uopće ni ne treba razmatrati u kontekstu zabrane reformatio in peius utemeljene čl. 118. st. 2. ZUP-a.

38 Sâma regulacija instituta reformatio in peius u upravnom postupku svoje uporište prije svega 
ne može zauzeti ekstenzivan pristup, nego da se navedena odredba mora tumačiti vrlo strogo i usko.

Zbog toga autor smatra da je potrebno bez imalo dvojbe odbaciti mogućnost da je reformatio in peius moguća i zbog razloga na temelju kojih drugostupanjsko tijelo u žalbenom postupku može poništiti rješenje. ${ }^{39}$ Kada bi se zauzelo takvo stajalište omogućio bi se reformatio in peius zbog svih, u hrvatskom upravnom pravu prepoznatih, oblika nezakonitosti. Time bi se negirala izrijekom utvrđena želja zakonodavca da reformatio in peius bude stroga iznimka, te bi ona postala pravilo.

Stajalište je autora i da reformaciji in peius nema mjesta niti zbog razloga za obnovu postupka. Naime, zakonodavac navodeći razloge za obnovu postupka niti ne polazi od toga da će ti razlozi izvjesno dovesti do drukčijeg rješenja. On jednostavno prepoznaje da su određene pogreške takve da možda mogu dovesti do drukčijeg rješenja, ${ }^{40}$ te zbog toga i predviđa ponovno vođenje (obnovu) čitavog ili određenih dijelova postupka. Tek po završetku obnovljenog postupka nadležno će tijelo utvrditi treba li staro rješenje ostaviti na snazi ili zamijeniti novim. Čak i kod potrebe donošenja novog rješenja, zakonodavac izrijekom ne propisuje poništavanje kao isključivu mogućnost stavljanja starog rješenja izvan snage. Nadležno tijelo, naime, može ga ili poništiti ili ukinuti ovisno o svim okolnostima pojedinog slučaja.

Bilo koji od razloga navedenih u čl. 123. ZUP-a, prema tome, sam po sebi nužno ne dovodi čak niti do obnove postupka, a kamoli do poništavanja rješenja. Stoga, a polazeći opet od načelne zabrane reformatio in peius i potrebe vrlo restriktivnog tumačenja čl. 118. st. 2. ZUP-a, autor zaključuje da razlozi navedeni za obnovu postupka nisu takve prirode niti snage da bi ih zakonodavac mogao predvidjeti kao razloge koji bi dovodili do izmjene rješenja na štetu stranke u žalbenom upravnom postupku.

Autor se prema tome slaže, s razmišljanjima koja ističu da na štetu žalitelja drugostupanjsko tijelo može riješiti po žalbi, samo ako bi se ista nepravilnost koja je uočena u žalbenom postupku mogla otkloniti izvanrednim pravnim lijekovima, i to samo oglašavanjem rješenja ništavim, odnosno poništavanjem rješenja. ${ }^{41}$ Dakle,

nalazi u dominantno javnopravnom karakteru upravnog postupka i potrebi zaštite objektivne zakonitosti, uz postizanje odgovarajuće ravnoteže spram legitimnih očekivanja stranke. Alen Rajko, Žalba u upravnom postupku i reformatio in peius, Ius-Info, 3. siječnja 2017., https:// www.iusinfo.hr/aktualno/u-sredistu/28707.

39 Navedeno stajalište zauzeo je Turčić. V. Zlatan Turčić, Komentar Zakona o općem upravnom postupku, s prilozima, sudskom praksom i abecednim kazalom pojmova, Zakoni o upravnim sporovima, s prilozima i abecednim kazalom pojmova (Zagreb: Organizator, 2012.), 265-266. Turčić ističe i da je reformatio in peius moguća i zbog razloga za poništavanje navedenih u čl. 129. st. 2. i 3. ZUP-a, dakle kod izvanrednoga pravnog lijeka poništavanja i ukidanja po pravu nadzora, kao i kod obnove postupka kada rješenje može biti poništeno zbog svih razloga zbog kojih se obnova može tražiti (čl. 123. st. 1. i 2. ZUP-a).

40 Sukladno čl. 126. st. 2. ZUP-a nadležno tijelo će, ako su uvjeti za obnovu postupka ispunjeni, ispitati mogu li okolnosti, odnosno dokazi koji se iznose kao razlog za obnovu dovesti do drukčijeg rješenja. Ako utvrdi da ne mogu, prijedlog će odbiti rješenjem.

41 V. Đerđa, Opći upravni postupak u Republici Hrvatskoj, 265; Rajko, Žalba u upravnom postupku i reformatio in peius i Frane Staničić, „Pitanje zabrane reformatio in peius u upranosudskoj 
do reformacije in peius u postupku u povodu žalbe može doći samo zbog razloga koji su propisani u čl. 128. i 129. ZUP-a. ${ }^{42}$

Napominjemo da je propust zakonodavca u uređivanju izmjene rješenja $u$ žalbenom upravnom postupku i neuvrštavanje mogućnosti ulaženja u reformatio in peius kada drugostupanjsko tijelo utvrdi da bi vršenje ovlaštenja iz rješenja moglo ugroziti nečiji život i zdravlje ili javnu sigurnost. ${ }^{43}$ Bilo bi i nelogično i vrlo štetno čekati da se navedena opasnost najprije realizira, a tek onda ukinuti rješenje. ${ }^{44}$

Posebno važno pitanje u okviru problematike reformatio in peius jest pitanje je li ona konzumirana jedino primjenom razloga za oglašavanje rješenje ništavim ili poništavanje pravomoćnog rješenja. Ističe se, tako, (za razliku od ranije navedenog stajališta razvijenog u kaznenoprocesnom pravu) kako ona faktički dolazi do izražaja i kada drugostupanjsko tijelo utvrdi da su u prvostupanjskom postupku činjenice utvrđene nepotpuno ili pogrešno pa je potrebno upotpuniti postupak utvrđivanja činjenica. Ako drugostupanjsko tijelo samo upotpuni postupak i nađe da se na temelju činjenica utvrđenih u upotpunjenom postupku stvar mora riješiti drukčije nego što je riješena prvostupanjskim rješenjem, ono će svojim rješenjem poništiti prvostupanjsko rješenje i samo riješiti stvar. ${ }^{45}$ Ako, pak, drugostupanjsko tijelo iz istog razloga poništi prvostupanjsko rješenje i predmet vrati prvostupanjskom tijelu na ponovni postupak (što može učiniti samo kada je s obzirom na prirodu upravne stvari nužno rješavanje prvostupanjskog tijela) s uputom kako treba upotpuniti postupak, do istog rezultata u upotpunjenom postupku može doći i prvostupanjsko tijelo. Navodi se kako bi u oba navedena slučaja bila moguća reformatio in peius na osnovi temelju izmijenjenoga činjeničnog stanja, a razlika je jedino u tome što je rješenje drugostupanjskog tijela ujedno konačno rješenje, dok je protiv novog rješenja prvostupanjskog tijela moguća žalba. ${ }^{46}$

praksi“, Informator, br. 6605 (2019): 20.

42 Za raspravu svakako ostaje pitanje jesu li zaista svi razlozi navedeni u čl. 129. ZUP-a takve prirode i važnosti da ih treba propisati kao razloge za poništavanje pravomoćnih rješenja (a samim time i kao iznimka od načelne zabrane reformatio in peius)? No, mišljenje je autora da odgovor na navedeno pitanje nadilazi okvire rada te zaslužuje ozbiljnu analizu u posebnom radu.

43 Navedeni razlog može dovesti do primjene izvanrednoga pravnog sredstva ukidanja zakonitog rješenja kojim je stranka stekla neko pravo. Čl. 130. st. 1. t. 3. ZUP-a određuje, naime, da se zakonito rješenje kojim je stranka stekla neko pravo može ukinuti u cijelosti ili djelomično: ako je to potrebno zbog otklanjanja teške i neposredne opasnosti za život i zdravlje ljudi i javnu sigurnost, ako se to ne bi moglo otkloniti drugim sredstvima kojima bi se manje diralo u stečena prava.

44 Pa zatim, može se postaviti i pitanje zbog čega drugostepeni organ ne bi smio rješavati in peius žalitelja poništavanjem prvostepenog rješenja ako je stranka samo djelomično zadovoljna, ali vršenje ovlaštenja koje bi njime stekla može neposredno ugroziti nečije zdravlje ili život? Valjda ipak ne treba čekati da se ta opasnost realizira, pa da se tek onda opozove rješenje! V. Ivančević, Institucije upravnog prava, 425.

45 V. čl. 117. st. 1. t. 1. ZUP-a.

46 V. Ivančević, Institucije upravnog prava, 424-425. Također v. i dugogodišnju upravnosudsku praksu koja zauzima navedeno stajalište, npr. presuda Upravnog suda Hrvatske, Us-322/81 od 29. rujna 1981. i presuda Upravnog suda Republike Hrvatske, Us-8103/2006-6 od 11. studenog 2010 . 
Vezano za navedeno pitanje u teoriji, ali i u upravnosudskoj praksi tijekom vremena su se razvila tri gledišta.

Prema jednom gledištu, tako, načelo zabrane reformatio in peius mora se promatrati i tumačiti u sklopu načela zakonitosti i načela materijalne istine. Prema spomenutom gledištu, načelo zabrane reformacije in peius uvedeno je ponajprije radi zaštite interesa društvene zajednice, a tek u drugom redu radi zaštite interesa žalitelja. Međutim, interesi zajednice i interesi žalitelja ne mogu biti u sukobu. Stoga se ostvarivanjem zaštite interesa društvene zajednice istodobno ostvaruje i zaštita interesa žalitelja. Prema tome, svrha je izjavljivanja žalbe od žalitelja uklanjanje pogreški i donošenje pravilnijeg i na zakonu utemeljenijeg rješenja, što je u skladu i s načelom materijalne istine i s načelom zakonitosti. Mada to gledište nastoji načelo zabrane reformatio in peius tumačiti samo u sklopu primjene načela materijalne istine i načela zakonitosti, ono pri svemu tom teži i za tim da opravda načelo zabrane reformatio in peius. Stoga prema tom gledištu, nadležno tijelo ipak ne može izmijeniti prvostupanjsko rješenje na štetu žalitelja ako je njime povrijeđen zakon u njegovu korist, no samo uz uvjet da je riječ o istom činjeničnom stanju na temelju kojeg je prvostupanjsko rješenje bilo doneseno. ${ }^{47}$

Međutim, prema tom gledištu, ne bi bilo mjesta primjeni načela zabrane reformatio in peius kad bi se bilo u postupku pred drugostupanjskim tijelom, bilo u postupku pred prvostupanjskim tijelom, koji je uslijedio na temelju poništenja rješenja od strane drugostupanjskog tijela, saznalo za nove činjenice i dokaze. U tom je slučaju nadležno tijelo ovlašteno stvar riješiti na štetu žalitelja. ${ }^{48}$

Navedene ovlasti drugostupanjskoga tijela opravdavaju se interesom društvene zajednice da upravna stvar bude riješena na način kako to nalaže stvarno činjenično stanje i kako to predviđaju zakonski propisi. ${ }^{49}$

Prema drugom gledištu, ratio legis načela zabrane reformatio in peius je u tome da se strankama osigura što šire pravo na podnošenje žalbe i da se stranke oslobode od straha da će u povodu izjavljene žalbe pogoršati svoj pravni položaj i da će se predmetna upravna stvar riješiti na njihovu štetu. Prema tome, ako je žalbu podnijela samo stranka koja u konkretnoj upravnoj stvari traži poboljšanje svoga pravnog položaja, a nije riječ o angažiranju kvalificiranoga javnog interesa o kojem se radi o slučajevima koji su izričitom zakonskom odredbom predviđeni kao iznimke od načelne zabrane reformatio in peius, razlozi pravičnosti i humanosti nalažu da žalitelj zbog podnesene žalbe ne može biti stavljen u gori položaj, no što bi ga imao da uopće nije podnio žalbu. Drukčije rješenje navedenog pitanja, tj.

U spomenutom kontekstu nužno je navesti i presudu Visokog upravnog suda Republike Hrvatske, Us-4005/11 od 17. srpnja 2014., u kojem je sud istaknuo da $u$ žalbenom postupku nisu ispunjeni uvjeti za rješavanje upravne stvari na štetu žalitelja u smislu odredbe članka 244. stavka 2. ZUP-a u svezi s člankom 263. stavkom 2. ZUP-a, jer u konkretnom slučaju prvostupanjskim rješenjem nije povrijeđen materijalni zakon već je pogrešno izveden zaključak o činjeničnom stanju. Navedenom je presudom Visoki upravni sud ispravno odijelio pogrešku u utvrđivanju činjeničnoga stanja od povrede materijalnog propisa.

47 V. Popović, Komentar Zakona o opštem upravnom postupku, 571.

48 Popović, Komentar Zakona o opštem upravnom postupku, 571.

49 Popović, Komentar Zakona o opštem upravnom postupku, 571. 
dopuštanje široke mogućnosti izmjene rješenja na štetu žalitelja moglo bi ograničiti stranci pravo na žalbu..$^{50}$

Prema tom gledištu, načelo zabrane reformatio in peius, koje je uvedeno zbog iznesenih razloga, tj. ponajprije u korist stranke (žalitelja) u svrhu zaštite njenih interesa, zapravo je iznimka od načela materijalne istine i načela zakonitosti. U tim slučajevima, prema tome, da bi se omogućilo načelo zabrane reformatio in peius, ne dolaze u punom opsegu do primjene načela materijalne istine i načela zakonitosti. ${ }^{51}$

Stoga, ako je žalitelj osporavao prvostupanjsko rješenje zbog pogrešne primjene materijalnog prava, ili zbog bitnih povreda pravila upravnog postupka, drugostupanjsko, odnosno prvostupanjsko tijelo, ne može riješiti žalbu na štetu žalitelja, pa i ako bi se i u postupku pred drugostupanjskim tijelom, odnosno u postupku pred prvostupanjskim tijelom, koji bi nastao nakon izvršenja drugostupanjskog rješenja kojim je prvostupanjsko rješenje poništeno zbog povrede odredaba upravnog postupka, saznalo za nove činjenice ili nove dokaze. Prema tome, ako žalitelj svojom žalbom nije osporavao prvostupanjsko rješenje zbog pogrešno ili nepotpuno utvrđenoga činjeničnog stanja, tijelo nadležno za rješavanje u upravnom postupku, nije ovlašteno utvrđivati novo činjenično stanje te na temelju njih i dokaza rješava pravno pitanje na štetu žalitelja. ${ }^{52}$

I po tom drugom gledištu nema mjesta primjeni načela zabrane reformatio in peius ako je žalitelj osporavao prvostupanjsko rješenje zbog pogrešno ili nepotpuno utvrđenoga činjeničnog stanja ili kad je žalitelj koristeći ustanovu beneficium novorum iznio u žalbi nove činjenice i dokaze. U tom se slučaju žalitelj izlaže riziku da u postupku pred drugostupanjskim ili prvostupanjskim tijelom, na temelju novo provedenog postupka i novih činjenica i dokaza, upravna stvar bude riješena na njegovu štetu. Takvo rješenje proizlazi iz prirode žalbe kojom se osporava činjenično stanje. Stoga, ako se u postupku u povodu žalbe pojave i neke činjenice i dokazi na koje žalitelj nije ukazivao i koje mogu izazvati za žalitelja nepovoljnije rješenje pitanja, on se ne može pozvati na načelo zabrane reformatio in peius, jer je ono protivno pravnoj prirodi postupka koji je uslijedio u povodu žalbe. ${ }^{53}$

Treće, i najnovije, gledište nadovezuje se na argumente iz drugog opisanog gledišta, ali problematici pogrešno ili nepotpuno utvrđenog činjeničnog stanja pristupa još strože. U njemu se ističe da se rješenje nikako ne može izmijeniti na štetu žalitelja zbog naknadnoga utvrđenja činjeničnog stanja koje se razlikuje od onoga u pobijanom rješenju. Prema tome (što prešutno proizlazi iz navedenoga stajališta) niti ako je žalitelj u žalbi osporavao prvostupanjsko rješenje zbog pogrešno ili nepotpuno utvrđenoga činjeničnog stanja. Argumenti za navedenu tvrdnju nalaze

50 Popović, Komentar Zakona o opštem upravnom postupku, 571.

51 Popović, Komentar Zakona o opštem upravnom postupku, 571.

52 Popović, Komentar Zakona o opštem upravnom postupku, 572.

53 Popović, Komentar Zakona o opštem upravnom postupku, 572.

I takvo je stajalište prisutno u sudskoj praksi: Ako je stranka pobijala žalbom pravilnost utvrđenih činjenica $i$ ako je drugostupanjski organ u nadopunjenom postupku pravilno utvrdio te činjenice i na osnovi njih našao da stvar treba riješiti drukčije, može izmijeniti prvostupanjsko rješenje na štetu žalitelja tako da poništi prvostupanjsko rješenje $i$ sam riješi stvar. Zaključak sudaca Upravnog suda Hrvatske od 15. prosinca 1989. 
se ponajprije u zakonskom tekstu. Naime ZUP izričito dopušta interveniranja u prvostupanjska rješenja u žalbenom postupku na štetu stranke samo iz razloga zbog kojih bi se na to rješenje mogli primijeniti izvanredni pravni lijekovi oglašavanja rješenja ništavim ili poništavanja rješenja (ako posebnim zakonom nije drukčije propisano).$^{54}$ Ističe se i kako se načelnom zabranom reformacije in peius štite i legitimna očekivanja stranke te ustavno načelo pravne sigurnosti..$^{55}$

Mišljenje je autora da se načelo zabrane reformatio in peius u upravnom postupku može prihvatiti jedino pod uvjetima navedenim u posljednjem opisanom gledištu. Reformatio in peius predviđena je čl. 118. st. 2. ZUP-a kao stroga iznimka samo kod postojanja nezakonitosti u rješenju koje bi mogle dovesti do oglašivanja rješenja ništavim (čl. 128. ZUP-a) i poništavanja rješenja (čl. 129. ZUP-a). ZUP, dakle, pogrešno ili nepotpuno utvrđeno činjenično stanje ne navodi kao nezakonitost koja bi mogla dovesti do izmjene rješenja na štetu žalitelja. Cjelokupnim uređenjem pitanja reformacije in peius u ZUP-u zakonodavac je želio uskladiti često suprotstavljene interese u upravnom postupku - interese stranaka i javni interes, kao i često međusobno oprečna načela - načelo materijalne istine i zakonitosti s jedne strane te pravne sigurnosti s druge. No, ponajprije je želio osigurati pravo na žalbu te uspostaviti takav sustav u kojem će stranke žalbe moći izjavljivati slobodno i bez straha od štetnih posljedica. Zbog toga je i propisao načelnu zabranu reformatio in peius, te ju ograničio (zbog zaštite javnog interesa) isključivo u slučajevima postojanja nezakonitosti koji su takve snage da se zbog njih mogu osporavati i pravomoćni akti. Stoga autor smatra da je širenje razloga koji mogu dovesti do reformacije na štetu stranke izvan razloga propisanih čl. 118. st. 2. ZUP-a (pa tako i na pogrešno ili nepotpuno utvrđeno činjenično stanje) $u$ suprotnosti s odredbama ZUP-a, ali potencijalno i u suprotnosti s načelima koja su ranije navedena u tekstu rada. ${ }^{56}$

Pravna praksa davno je zauzela i stajalište s kojim se također autor ne slaže. Prema njemu se zabrana reformatio in peius odnosi samo na drugostupanjsko rješenje o žalbi stranke u upravnom postupku, a ne i na ponovno rješavanje prvostupanjskog tijela. ${ }^{57}$

Autor smatra kako je i navedeno stajalište pogrešno i suprotno sa smislom uspostavljanja načelne zabrane reformatio in peius, ali i sa smislom žalbe kao redovitog i osnovnoga pravnog sredstva u upravnom postupku.

Jedno je od osnovnih značajki žalbe i u upravnom postupku njezina devolutivnost - prenošenje nadležnosti za odlučivanje o određenoj upravnoj stvari

54 Rajko, Žalba u upravnom postupku i reformatio in peius i Staničić, Pitanje zabrane reformatio in peius u upranosudskoj praksi, 20 i 23.

55 V. Rajko, Žalba u upravnom postupku i reformatio in peius i Staničić, Pitanje zabrane reformatio in peius u upranosudskoj praksi, 23. Staničić u svom radu detaljno analizira odluku Ustavnog suda Republike Hrvatske U-III-2507/2016 od 9. listopada 2019. koja se u osnovi odnosi na pitanje reformatio in peius u upravnom sporu.

56 Čl. 118. st. 2. ZUP-a izrijekom predviđa mogućnost da se posebnim zakonom propišu i razlozi koji dopuštaju reformatio in peius i izvan onih navedenih u ZUP-u. O navedenoj mogućnosti govorit ćemo na kraju poglavlja rada.

57 V. presudu Vrhovnog suda Republike Hrvatske, br. U-2072/62 od 1. veljače 1963. 
s tijela nižega stupnja na tijelo višeg stupnja. ${ }^{58}$ Devolutivna priroda žalbe proizlazi i nadovezuje se na hijerarhijski ustroj javnopravnih tijela, ${ }^{59}$ prema kojemu, hijerarhijski viša javnopravna tijela nadziru rad hijerarhijski nižih javnopravnih tijela.

$\mathrm{S}$ obzirom na navedeno, ovlasti drugostupanjskog tijela $\mathrm{u}$ postupanju u povodu žalbe šire su od onih koje ima prvostupanjsko tijelo. Navedene ovlasti tako uključuju i mogućnost odbijanja žalbe. To dakako, prvostupanjsko tijelo ne može činiti jer bi se time negirao smisao devolutivnoga djelovanja žalbe, pa time i smisao žalbe kao pravnog lijeka. Mogućnošću poništavanja prvostupanjskog rješenja, zakonski je izražen hijerarhijski nadređeni položaj drugostupanjskoga tijela. Tako će drugostupanjsko tijelo, nakon što je prvostupanjsko rješenje poništilo, u pravilu samo riješiti upravnu stvar, a iznimno, kad je za donošenje novog rješenja, s obzirom na prirodu upravne stvari, nužno rješavanje prvostupanjskog tijela, dostaviti predmet na ponovno rješavanje prvostupanjskom tijelu. Iako zakon o tome izričito ne govori, pri ponovnom odlučivanju prvostupanjsko je tijelo vezano s pravnim shvaćanjima drugostupanjskog tijela i pri ponovnom vođenju postupka obvezno je postupati prema drugostupanjskom rješenju. ${ }^{60} \mathrm{I}$ takva je vezanost logična posljedica hijerarhijskih odnosa, tj. podređenosti prvostupanjskog tijela drugostupanjskom tijelu.

Prema tome, institut žalbe u upravnom postupku zakonodavac je uredio tako da je propisao postupak i ovlasti i prvostupanjskog i drugostupanjskog tijela u radu u povodu žalbe. No, time nije uredio dva odvojena i samostalna postupka. Riječ je o jednom cjelovitom postupku koji je, ponajprije zbog razloga učinkovitosti i ekonomičnosti te jačanja položaja stranke, razdijeljen u dvije etape ${ }^{61}$ Drugostupanjsko tijelo u takvoj je cjelini u hijerarhijski višem položaju

58 Jednoje od važnijih svojstava žalbe u tome što se njenim izjavljivanjem nadležnost za odlučivanje u predmetu prenosi na drugostupanjsko tijelo odnosno tijelo nadležno za odlučivanje o žalbi (devolutivno djelovanje žalbe). Borković, Upravno pravo, 459.

Žalba je devolutivni pravni lijek. Izjavljivanjem žalbe postupanje prvostupanjskog tijela u rješavanju upravne stvari podvrgava se nadzoru hijerarhijski višeg - drugostupanjskog tijela, čime se osigurava provođenje upravnog nadzora nad donošenjem odluka o pravima i interesima građana. Devolutivni učinak žalbe omogućuje stranci koja smatra da su joj rješenjem prvostupanjskog tijela povrijeđena prava i obveze da prije okončanja upravnog postupka zatraži nadzor zakonitosti i pravilnosti donesenog rješenja od hijerarhijski višeg tijela. Upravo devolutivnost razlikuje žalbu od drugih pravnih sredstava unutar uprave, kao što je, primjerice, prigovor. Đerđa, Opći upravni postupak u Republici Hrvatskoj, 240-241.

59 O višim i nižim tijelima uprave i hijerarhiji v. u: Borković, Upravno pravo, 209, 244-245.

60 Prvostupanjskom tijelu se zahtjev može vratiti na ponovni postupak samo u slučajevima kada je s obzirom na prirodu upravne stvari nužno neposredno rješavanje upravne stvari od prvostupanjskog tijela. No i u takvom slučaju drugostupanjsko tijelo trebalo bi svojim rješenjem uputiti prvostupanjsko tijelo u to što treba učiniti u postupku i po toj bi uputi prvostupanjsko tijelo trebalo u svemu postupiti. Đerđa, Opći upravni postupak u Republici Hrvatskoj, 266.

61 Razloge takvog širenja ovlaštenja prvostepenog organa preko procesnih pitanja $i$ na materijalnopravna nije teško pogoditi: to su razlozi ekonomičnosti, ubrzanja postupka i napose tendencije da se olakša procesni položaj stranke neposrednim kontaktom s organom koji može popraviti vlastitu grešku bez rizika da ponavljanjem rješavanja stranka izgubi pravnu zaštitu u nastavku upravnog postupka. Ivančević, Institucije upravnog prava, 420. 
koji je i iskazan širim i nadzornim ovlastima, a one uključuju i kasaciju i meritorno rješavanje.

Mišljenje je autora da se i uređenje izmjene rješenja, tj. načelne zabrane reformatio in peius svakako treba promatrati u opisanim okvirima i ovlastima.

Pritom drži, da odredbu čl. 118. st. 1. ZUP-a, koja propisuje da „drugostupanjsko tijelo ne može izmijeniti prvostupanjsko rješenje na štetu stranke koja je izjavila žalbu“, treba tumačiti kao generalnu zabranu reformatio in peius u upravnom postupku. Ako bi se prihvatilo stajalište razvijeno u upravnosudskoj praksi, prema kojem prvostupanjska tijela takvom zabranom nisu vezana, proširila bi se ovlast prvostupanjskog tijela tako da bi ono u pogledu reformacije rješenja imalo šire ovlasti od drugostupanjskog tijela. Autor smatra da bi se time negirao hijerarhijski viši položaj drugostupanjskog tijela i njegove nadzorne ovlasti, a i sam smisao zabrane reformatio in peius. Jednostavnije rečeno zakonodavac bi izričitim propisivanjem zabrane reformatio in peius za drugostupanjsko tijelo, tim više propisao i zabranu navedene reformacije i za prvostupanjsko tijelo. ${ }^{62}$

Prema čl. 118. st. 2. ZUP-a posebnim se zakonima mogu propisati razlozi koji omogućuju ulazak u reformatio in peius i izvan onih navedenih u čl. 128. i 129. ZUP-a. Autor smatra, naime, da ta mogućnost nedvojbeno proizlazi iz konstrukcije „ako nije drukčije propisano“ u čl. 118. st. 2. ZUP-a. ${ }^{63} \mathrm{~S}$ obzirom na to da je zakonodavac, svjestan širine i raznolikosti javne uprave, čl. 3. st. 1. ZUP-a propisao je mogućnost da se posebnim zakonima određena pitanja postupka urede drukčije nego što su uređena ZUP-om. Autor smatra da nije ništa sporno u tome što je takvu mogućnost zakonodavac posebno naglasio i u čl. 118. st. 2. ZUP-a. Nužno je pritom istaknuti kako čl. 3. st. 1. ZUP-a određuje da se pri drukčijem reguliranju postupovne materije u posebnim zakonima to smije činiti samo za pojedina pitanja u postupku, samo onda kad je to nužno i samo na način koji ne smije biti suprotan s temeljnim odredbama (pa, tako - i posebno, načelnim odredbama) i svrhom ZUP-a.

Prema tome i pri propisivanju reformatio in peius u posebnim se zakonima navedena ograničenja moraju poštovati. Autor smatra, da bi se reformacija in peius mogla širiti izvan okvira (tj. razloga) utvrđenih ZUP-om samo u „ekstremnim“ i izvanrednim situacijama kada je potrebno štiti vrijednosti najvišeg ranga - u prvom redu život i zdravlje ljudi. Dakako, i prilikom takve regulacije moralo bi se u potpunosti uvažavati načela upravnog postupka - prvenstveno pravo stranke na pravni lijek ( $\mathrm{tj}$. konkretno pravo na žalbu) te načelo razmjernosti.

\section{ZAKLJUС̆AK}

Žalba kao najvažnije pravno sredstvo u upravnom postupku, u cjelini gledano, odredbama ZUP-a uređena je temeljito i kvalitetno. Ozbiljne zamjerke u navedenom

62 Ipak, ma kolikoje ZUP... proširio ovlaštenja prvostepenog organa da može odlučivati meritorno povodom uložene žalbe, postoji i za njega ograničenje u zabrani reformacije in peius žalitelja. Ivančević, Institucije upravnog prava, 420.

63 Čl. 244. st. 2. ZUP-a 1991. navedenu konstrukciju nije obuhvaćao pa izrijekom nije niti predviđao reformatio in peius izvan razloga predviđenih u njegovim čl. 263., 266. i 267. 
uređenju mogu se uputiti jedino odredbi čl. 118. ZUP-a kojim je propisana mogućnost izmjene rješenja u žalbenom stadiju upravnog postupka.

Zakonodavac je navedenom odredbom propustio urediti brojna pitanja koja nameće izmjena rješenja. Tako nije propisao mogućnost izmjene pobijanog rješenja u korist stranke (reformatio in melius). Prema shvaćanju autora to je morao učiniti, ponajprije zbog toga da bi postavio granice takve reformacije, ali i zbog potrebe propisivanja izmjene zakonitih i pravilnih rješenja kada bi se njihova svrha mogla ostvariti primjenom sredstava koja su povoljnija za stranku.

Vezano za mogućnost izmjene pobijanog rješenja na štetu stranke (reformatio in peius) zakonodavac je zauzeo ispravan pristup kada je propisao načelnu zabranu takve reformacije. Nažalost, nepreciznošću regulacije ostavio je prostor za tumačenja koja mogućnosti za izmjenu rješenja na štetu žalitelja pronalaze i u razlozima koje, prema mišljenju autora, zakonodavac nije imao u vidu. Stoga smatra da razloge za reformatio in peius treba tražiti isključivo u čl. 128. i 129. ZUP-a koji uređuju izvanredna pravna sredstva oglašavanja rješenja ništavim i poništavanja i ukidanja nezakonitog rješenja.

Mišljenje je autora, naposljetku, da je u pogledu reformatio in peius razvijena praksa koja nije u skladu sa zakonski propisanom načelnom zabranom takve reformacije. Prema takvoj praksi, naime, kada se u upotpunjenom postupku koji je uslijedio nakon poništavanja pobijanog rješenja utvrdi da na temelju činjenica utvrđenih u takvom postupku upravna stvar mora riješiti drukčije nego što je riješena pobijanim rješenjem, nadležno tijelo (bilo drugostupanjsko bilo prvostupanjsko) može stvar riješiti i na štetu žalitelja. U radu se stoga zalaže za napuštanje takve prakse koja, u osnovi, dovodi u pitanje načelnu zabranu reformatio in peius.

Autor smatra da treba napustiti i praksu prema kojoj zabranom reformacije in peius nisu vezana prvostupanjska, već samo drugostupanjska tijela. Takvom se praksom negira i načelna zabrana reformatio in peius, ali i devolutivnost žalbe te hijerarhijski nadređeni položaj drugostupanjskih tijela.

$\mathrm{S}$ obzirom na važnost zabrane reformatio in peius u upravnom postupku autor se nada da će potaknuti zakonodavca da pri mogućim izmjenama i dopunama ZUP-a obrati pozornost i na pitanje kvalitetnijeg i podrobnijeg uređivanja navedene materije. Nada se da će potaknuti i javnopravna tijela i upravne sudove da preispitaju u radu opisanu praksu koja je, prema mišljenju autora, u suprotnosti s načelnom zabranom reformatio in peius.

\section{LITERATURA}

1. Borković, Ivo. Upravno pravo. Zagreb: Narodne novine, 2002.

2. Đerđa, Dario. Opći upravni postupak u Republici Hrvatskoj. Zagreb: Inženjerski biro, 2010.

3. Gagro, Božo. „Postupanje po žalbi prema novom Zakonu o općem upravnom postupku“. U: Modernizacija općeg upravnog postupka i javne uprave u Hrvatskoj, eds. Ivan Koprić i Vedran Đulabić, 181-190. Zagreb: Suvremena javna uprava, 2009.

4. Ivančević, Velimir. Institucije upravnog prava. Zagreb: Pravni fakultet u Zagrebu, 1983.

5. Krapac, Davor. Kazneno procesno pravo, prva knjiga: institucije. Zagreb: Narodne novine, 2015. 
6. Krbek, Ivo. Zakon o opštem upravnom postupku. Zagreb: Tisak jugoslovenske štampe d.d., 1931.

7. Popović, Slavoljub. Komentar Zakona o opštem upravnom postupku. Beograd: Savremena administracija, 1987.

8. Rajko, Alen. „Zamjena i izmjena rješenja u prvostupanjskom upravnom postupku“. IusInfo, 15. ožujka 2016., https://www.iusinfo.hr/aktualno/u-sredistu/25513.

9. Rajko, Alen, „Žalba u upravnom postupku i reformatio in peius“, Ius-Info, 3. siječnja $2017 \mathrm{https}: / /$ www.iusinfo.hr/aktualno/u-sredistu/28707.

10. Staničić, Frane, „Pitanje zabrane reformatio in peius u upranosudskoj praksi“. Informator, br. 6605 (2019): 20-23.

11. Triva, Siniša. Rječnik građanskog procesnog prava. Zagreb: Informator, 1968.

12. Triva, Siniša i Mihajlo Dika. Građansko parnično procesno pravo. Zagreb: Narodne novine, 2004.

13. Turčić, Zlatan. Komentar Zakona o općem upravnom postupku, s prilozima, sudskom praksom i abecednim kazalom pojmova, Zakoni o upravnim sporovima, s prilozima $i$ abecednim kazalom pojmova. Zagreb: Organizator, 2012.

14. Upravni sud Hrvatske, Us-322/81 od 29. rujna 1981.

15. Upravni sud Republike Hrvatske, Us-8103/2006-6 od 11. studenog 2010.

16. Ustav Republike Hrvatske, Narodne novine, br. 56/90., 135/97., 113/00., 28/01., 76/10. i $5 / 14$.

17. Ustavni sud Republike Hrvatske, U-III-2507/2016 od 9. listopada 2019.

18. Visoki upravni sud Republike Hrvatske, Us-4005/11 od 17. srpnja 2014.

19. Vrhovni sud Republike Hrvatske, U-2072/62 od 1. veljače 1963.

20. Zaključak sudaca Upravnog suda Hrvatske od 15. prosinca 1989.

21. Zakon o općem upravnom postupku, Narodne novine, br. 47/09.

22. Zakon o preuzimanju Zakona o općem upravnom postupku, Narodne novine, br. 53/91. i $103 / 96$.

23. Zakon o upravnim sporovima, Narodne novine, br. 20/10., 143/12., 152/14., 94/16. i $29 / 17$. 


\title{
Marko Šikić*
}

\author{
Summary
}

\section{AMENDING THE DECISION IN THE APPELLATE ADMINISTRATIVE PROCEDURE}

An appeal as a regular legal remedy in administrative proceedings is regulated by the provisions of the General Administrative Procedure Act of a fairly high quality. However, author think that the legislator has not fully regulated the procedure for amending the decission at the appeal stage of the administrative procedure. In order to prove this claim, author first analyze the possibilities of entering the reformatio in melius and reformatio in peius as the most important aspects of the mentioned phase of the the appeal procedure. Particular attention in the paper is paid to the issue of reformatio in peius because author belive that this issue is part of the very foundations of the regularion of the appeal as a legal remedy. In the conclusion of the paper, the basic theses presented in the paper are again summerized, and the desire for a more complete and efficent normative regulation of the possibility of amending the decision in the appellate administrative procedure is expressed.

Keywords: amending the decision; appeal; administrative procedure; reformatio in peius, reformatio in melius.

* Marko Šikić, Ph.D., Full Professor, Faculty of Law, University of Zagreb; marko.sikic@pravo. hr. ORCID: https://orcid.org/0000-0002-0146-9391. 
